IRSTI 532.5; 519.688

https://doi.org/10.47533/2020.1606-146X.123

B. T. ZHUMAGULOV ${ }^{1}$, D. B. ZHAKEBAYEV ${ }^{1,2 *}$, A. S. ZHUMALI', B. A. SATENOVA ${ }^{2}$

${ }^{1}$ National Engineering Academy of the Republic of Kazakhstan, Almaty, Kazakhstan

${ }^{2}$ Al-Farabi Kazakh National University, Almaty, Kazakhstan

\title{
LBM MODELING OF SOLID PARTICLE DYNAMICS IN A VISCOUS MEDIUM
}

This article discusses the mathematical and computer modeling of single solid particle dynamics in a viscous medium. The results of the study were obtained using a 3D numerical algorithm implemented on the basis of the D3Q19 model of the lattice Boltzmann method (LBM). The moving «liquid-solid» interface is accounted for using an interpolated bounce back (IBB) scheme.

The velocity of a solid particle motion and the trajectory of a particle at Re $=1,56$ are obtained. The results are in good agreement with the experimental and numerical results of other authors.

Key words: $L B M, I B B, D 3 Q 19$, solid particle, viscous medium.

Introduction. Fluid-particle systems are of significant scientific and technological interest in a wide range of disciplines. The problem of particle settling in a viscous fluid occurs in many natural and industrial applications such as the oil and paper industry, mineral ore processing, pollutant flow, blood cell transport in the human body, sediment transport, warm rain process, volcanic ash eruptions, dust storms and sea spray. In view of the importance of these applications, the problems of fluid-particle interaction have attracted considerable attention, both experimentally and numerically

Various numerical methods have been used to study solid particle fluxes involving the interaction of a dynamically evolving fluid and suspended solids. To accurately predict flow behavior, it is very important to study the interaction between fluid and particles. The interaction between particle and liquid affects the dynamics of suspended particles (e.g., dispersion, settling rate, collision frequency, settling rate) and bulk properties of multiphase flow (e.g., wall or surface resistance, turbulence intensity).

To date, many different formulations have been developed based on the Navier - Stokes $(\mathrm{N}-\mathrm{S})$ equation. The most commonly used numerical models for tracing the particle-liquid interface are: immersed boundary method [1], direct force method [2], local analytical method [3], overset- grid method [4], force - coupling [5] or penalization method [6 ].

In recent years, the lattice Boltzmann method (LBM) based on kinetic theory has received a lot of attention and has become a reliable tool for modeling problems with complex geometry, such as flow in a porous medium, interaction of fluid structures and turbulent flows loaded with particles [7]. This is a mesoscopic method based on the discrete Boltzmann equation. The main problem in these applications is the handling of the adhesion boundary condition at fluidsolid interfaces, which affects the overall accuracy, numerical stability, and computational efficiency of the lattice Boltzmann method. In LBM, there are two main methods for modeling the sticking boundary condition at fluid-solid interfaces, they are the immersed boundary method (IBM) and the interpolated bounce back method (IBB).

*E-mail корреспондирующего автора: dauren.zhakebayev@gmail.com 
Many LBM models have been developed for particle-loaded fluid flows [8]. In particular, for a fixed straight boundary, many different implementations of the boundary condition for velocity have been developed. One of the first interpolated bounce back schemes was proposed by Ladd [9], in which the particle surface is approximated as polylines in the form of a ladder. Previous studies have used a standard (or intermediate) rebound pattern, resulting in a curved boundary effectively approximating a zig-zag staircase. Later, improved proposed various interpolated rebound schemes were developed to more accurately represent the real liquid-solid interface [10]. In the model by Bouzidi et al. [11] a curved boundary scheme has been developed that does not require interpolation from a ghostly node inside a solid. The main idea of the scheme is to interpolate the distribution functions in the interior of the fluid and include additional information about the location of the wall during the rebound process. Recently, a one-node curvilinear boundary scheme was developed to simulate suspended particles, which were determined by Maxwell's iteration [12-13].

Although each boundary processing scheme has been separately tested and applied to different physical problems, as far as we know, they have yet to be systematically compared and evaluated under the same conditions.

The aim of this work is to develop a mathematical model of the settling of solid particles in a viscous fluid using the interpolated bounce back method based on solving Navier-Stokes equation, in which the momentum exchange method is used to find the hydrodynamic force acting on the particle surface. The numerical model is built on the basis of the LBM using the D3Q19 model. The accuracy and efficiency of the existing method have been tested on the basis of the test problem of the settling of a solid particle in a viscous medium. The results obtained are in good agreement with the experimental and numerical results of other authors.

Problem statement. Figure 1 shows the computational domain, which is a parallelepiped. The walls of the parallelepiped are impenetrable. All boundary conditions are constant in this work.

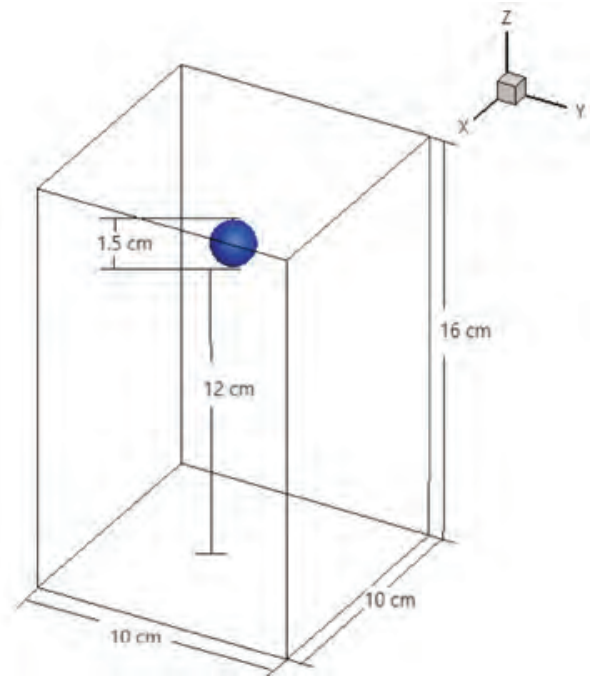

Figure 1 - Computational domain. 
The system of equations in three-dimensional space is as follows:

$$
\begin{gathered}
\operatorname{div} \vec{u}=0 \\
\frac{\partial \vec{u}}{\partial t}+(\vec{u} \cdot \nabla) \vec{u}=-\frac{1}{\rho_{f}} \nabla p+v_{f} \Delta \vec{u}
\end{gathered}
$$

where $\vec{u}$ is the velocity vector, $p$ is the pressure, $\rho_{f}$ is the fluid density, $v_{f}$ is the kinematic viscosity and $t$ is the time.

At the initial moment of time, as well as on the walls of the considered region, the fluid flow velocities are equal to zero.

The system of equations (1) - (2) can be reduced to a dimensionless form using the following dimensionless quantities:

$$
\begin{gathered}
\vec{x}^{*}=\frac{\vec{x}}{L}, \vec{u}^{*}=\frac{\vec{u}}{U_{0}}, \\
p^{*}=\frac{p L}{U_{0}}, \quad t^{*}=\frac{t U_{0}}{L}, \operatorname{Re}=\frac{U_{0} L}{v_{f}}
\end{gathered}
$$

where $\vec{u}^{*}$ is the dimensionless velocity components, $U_{0}$ is the characteristic velocity, $p^{*}$ is the dimensionless pressure, $t^{*}$ is the dimensionless time and Re is the Reynolds number.

The equations take the following dimensionless form:

$$
\begin{gathered}
\operatorname{div}^{*}=0 \\
\operatorname{Re}\left(\frac{\partial \vec{u}^{*}}{\partial t}+\left(\vec{u}^{*} \cdot \nabla\right) \vec{u}^{*}\right)=-\nabla p^{*}+\Delta \vec{u}^{*}
\end{gathered}
$$

Particle dynamics. The motion of a solid particle in a viscous medium is determined by the following equations:

$$
\begin{gathered}
M \frac{d \vec{u}_{b}}{d t}=\vec{F}-M\left(1-\frac{\rho_{f}}{\rho_{s}}\right) \vec{g}, \\
\frac{d \vec{X}}{d t}=\vec{u}_{b},
\end{gathered}
$$

where $M$ is the mass of solid particle, $\rho_{s}$ is the density of solid particle, $\vec{F}$ is the hydrodynamic force acting on a solid particle, $\vec{X}$ is the particle position.

Numerical method. The numerical solution in this work is based on the D3Q19 model of the lattice Boltzmann method [14]. The boundary condition between fluid and solid is determined by the IBB method [11]. The movement of a solid particle is carried out using the momentum exchange method [10].

The lattice Boltzmann equation in the Batnagar-Gross-Krook (BGK) approximation is as follows:

$$
f_{i}\left(\bar{x}+\vec{e}_{i} \Delta t, t+\Delta t\right)-f_{i}(\vec{x}, t)=-\frac{f_{i}(\vec{x}, t)-f_{i}^{e q}(\vec{x}, t)}{\tau_{f}}
$$


where $f_{t}$ is the velocity distribution functions, $\vec{e}_{i}$ is the discrete lattice speed, $\tau_{f}$ is the relaxation time, $\Delta t$ is the lattice time step, $f_{i}^{e q}$ is the equilibrium distribution function.

The equilibrium function is defined by the following formula:

$$
f_{i}^{e q}=\omega_{i} \rho\left[1+3 \frac{\vec{e}_{i} \vec{u}^{e q}}{c^{2}}+\frac{9}{2} \frac{\left(\vec{e}_{i} \vec{u}^{e q}\right)^{2}}{c^{4}}-\frac{3}{2} \frac{\vec{u}^{e q} \vec{u}^{e q}}{c^{2}}\right]
$$

where $c=\Delta x / \Delta t, \Delta x$ and $\Delta t$ are the lattice steps in space and time, which are equal to one. The following shows the weights in all directions:

$$
\omega_{i}= \begin{cases}1 / 3, & i=0 \\ 1 / 18, & i=1-6 \\ 1 / 36, & i=7-18\end{cases}
$$

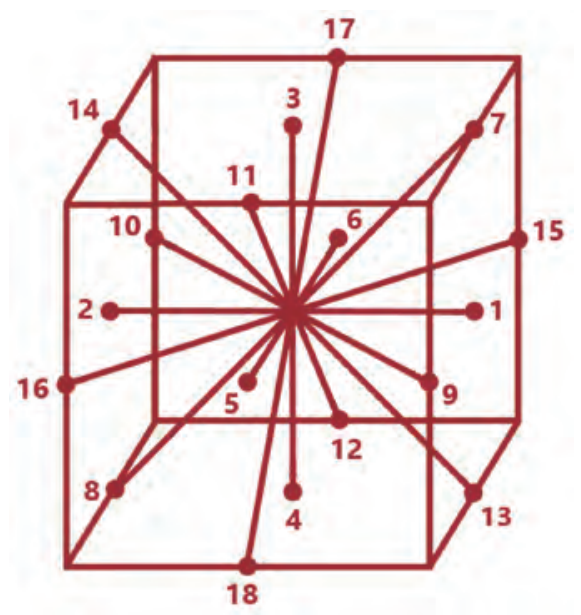

Figure 2 - D3Q19 model.

In the D3Q19 model (Fig. 2), discrete speeds are calculated using the following formula:

$$
\vec{e}_{i}=\left\{\begin{array}{lc}
(0,0,0) c, & i=0, \\
( \pm 1,0,0) c,(0, \pm 1,0) c,(0,0, \pm 1) c, & i=1-6 \\
( \pm 1, \pm 1,0) c,( \pm 1,0, \pm 1) c,(0, \pm 1, \pm 1) c, & i=7-18
\end{array}\right.
$$

The evolution equation is divided into two steps, collision and streaming:

1. $\tilde{f}_{i}(\vec{x}, t)=f_{i}(\vec{x}, t)-\frac{f_{i}(\vec{x}, t)-f_{i}^{e q}(\vec{x}, t)}{\tau_{f}}$

2. $\bar{f}_{i}\left(\vec{x}+\vec{e}_{i} \Delta t, t+\Delta t\right)=\tilde{f}_{i}(\vec{x}, t)$ 
After the second step, it is necessary to update the macroparameters (density, velocity) according to the following formulas:

$$
\rho=\sum_{i=0}^{18} \bar{f}_{i}, \quad \rho \vec{u}=\sum_{i=0}^{18} \bar{f}_{i} \vec{e}_{i}
$$

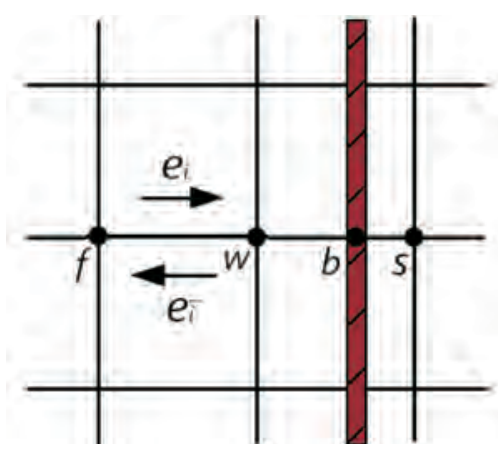

Figure 3 - «Fluid-solid particle» interface.

The following boundary conditions were used to close the system of equations. The bounce back rule was used to process the boundary condition on all walls [14]:

$$
f_{\bar{i}}\left(\vec{x}_{w}, t+\Delta t\right)=\tilde{f}_{i}\left(\vec{x}_{w}, t\right), \quad \vec{e}_{i} \cdot \vec{n}>0 .
$$

The bar above the index indicates the opposite direction.

To obtain the optimal condition at the moving solid-fluid interface, we use Bouzidi's interpolated bounce back scheme $[10,11]$ :

$$
\left\{\begin{array}{l}
f_{\bar{i}}\left(\vec{x}_{w}, t+\Delta t\right)=2 q \tilde{f}_{i}\left(\vec{x}_{w}, t\right)+(1-2 q) \tilde{f}_{i}\left(\vec{x}_{f}, t\right)+2 \omega_{i} \rho_{0} \frac{\vec{e}_{\bar{i}} \cdot \vec{u}_{b}}{c_{s}^{2}}, \quad q \leq 0.5, \\
f_{\bar{i}}\left(\vec{x}_{w}, t+\Delta t\right)=\frac{1}{2 q}\left(\tilde{f}_{i}\left(\vec{x}_{w}, t\right)+2 \omega_{i} \rho_{0} \frac{\vec{e}_{\bar{i}} \cdot \vec{u}_{b}}{c_{s}^{2}}\right)+\frac{2 q-1}{2 q} \tilde{f}_{\bar{i}}\left(\vec{x}_{w}, t\right), \quad q \geq 0.5
\end{array}\right.
$$

where $q=\frac{\vec{x}_{w}-\vec{x}_{b}}{\vec{x}_{w}-\vec{x}_{s}}, \vec{u}_{b}$ is the flow velocity on the surface of a solid particle, the location of the nodes $\vec{x}_{w}, \vec{x}_{f}, \vec{x}_{w}, \vec{x}_{b}, \vec{x}_{s}$ is shown in Figure 3 .

To determine the velocity and location of a solid particle, we approximate equations (6) - (7):

$$
\begin{gathered}
\vec{u}_{b}^{n+1}=\vec{u}_{b}^{n}+0.5 \Delta t \frac{\vec{F}^{n+1}+\vec{F}^{n}}{M}+\Delta t\left(1-\frac{\rho_{f}}{\rho_{s}}\right) \vec{g}, \\
\vec{X}^{n+1}=\vec{X}^{n}+0.5 \Delta t\left(\vec{u}_{b}^{n+1}+\vec{u}_{b}^{n}\right)
\end{gathered}
$$


To obtain the more accurate results, this article uses the momentum exchange method to find the hydrodynamic force [10]:

$$
\vec{F}=\sum_{\vec{x}_{w}} \sum_{i}\left(\tilde{f}_{i}\left(\vec{x}_{w}, t\right)+f_{\bar{i}}\left(\vec{x}_{w}, t+\Delta t\right)\right) \vec{e}_{i}
$$

It remains to find the distribution functions for the new nodes of the fluid that appeared during the displacement of the solid particle. For this, the averaged extrapolation procedure is applied [10]:

$$
\begin{aligned}
& f_{i, k}\left(\vec{x}_{n e w}, t+\Delta t\right)=2 f_{i}\left(\vec{x}_{\text {new }}+\vec{e}_{k} \Delta t, t+\Delta t\right)-f_{i}\left(\vec{x}_{\text {new }}+2 \vec{e}_{k} \Delta t, t+\Delta t\right), \\
& f_{i}\left(\vec{x}_{\text {new }}, t+\Delta t\right)=\frac{1}{N k} \sum_{k} f_{i, k}\left(\vec{x}_{\text {new }}, t+\Delta t\right),
\end{aligned}
$$

where $k$ means possible extrapolation directions and $N k$ is the number of possible extrapolation directions.

Simulation results. Numerical experiments were carried out to simulate the dynamics of a solid particle in a viscous medium. The length, width and height of the computational area are $10 \times 10 \times 16 \mathrm{~cm}$, respectively. At the initial moment of time, the solid sphere hangs at a distance $12 \mathrm{~cm}$ from the lower boundary of the parallelepiped (Figure 1). The required physical parameters are shown in Table 1.

Table 1 - Physical parameters

\begin{tabular}{|c|c|c|c|c|}
\hline$\rho_{f}$ & $\mu_{f}$ & $U_{0}$ & $\operatorname{Re}$ & $S_{t}$ \\
\hline$\left[\frac{g}{\mathrm{~cm}^{3}}\right]$ & {$\left[\frac{g}{\mathrm{~cm} \cdot \mathrm{s}}\right]$} & {$\left[\frac{\mathrm{cm}}{\mathrm{s}}\right]$} & & \\
\hline 0,97 & 3,37 & 4 & 1,56 & 2 \\
\hline
\end{tabular}

Figure 4 shows the change in the trajectory of a solid particle depending on time and comparison between LBM simulation and experimental solution obtained by ten Cate et al. [15]. Figure 5 demonstrates the vertical component of particle sedimentation velocity at different time instants in comparison with the experimental solution obtained by ten Cate et al. [15]. As can be seen from the figures, the numerical data agree well with the experimental data. In figures 6 and 7, you can see a 2D plot of vertical velocity profiles of solid particle and a $3 \mathrm{D}$ plot of solid particle sedimentation at different points in time. 


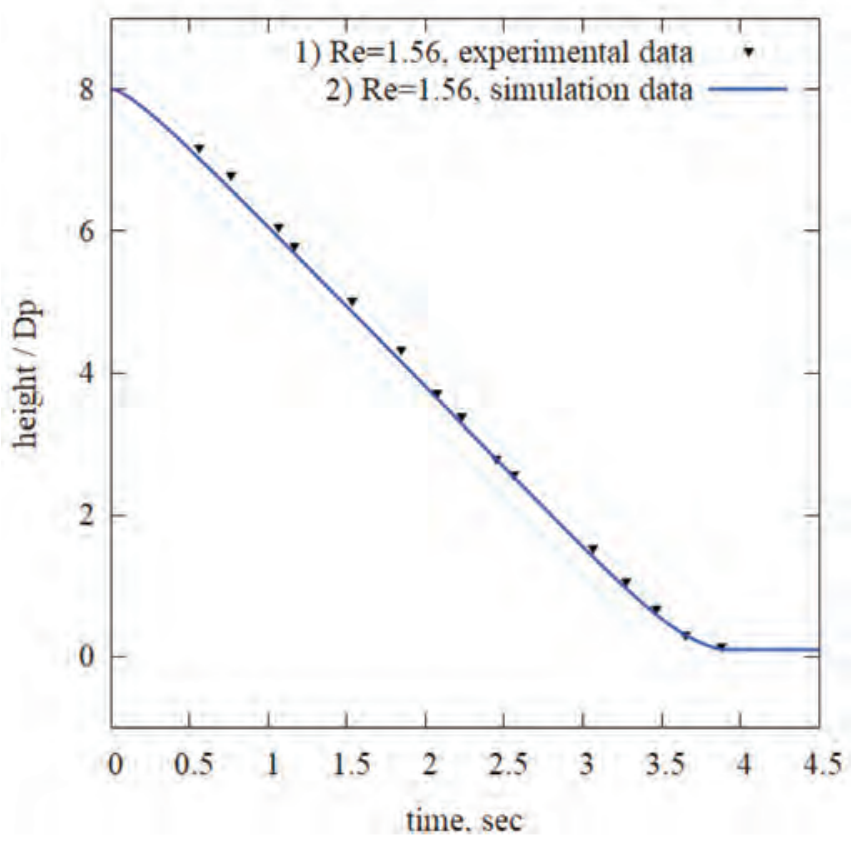

Figure 4 - Solid particle trajectory.

Comparison of the simulation data with experimental data at $\operatorname{Re}=1,56$.

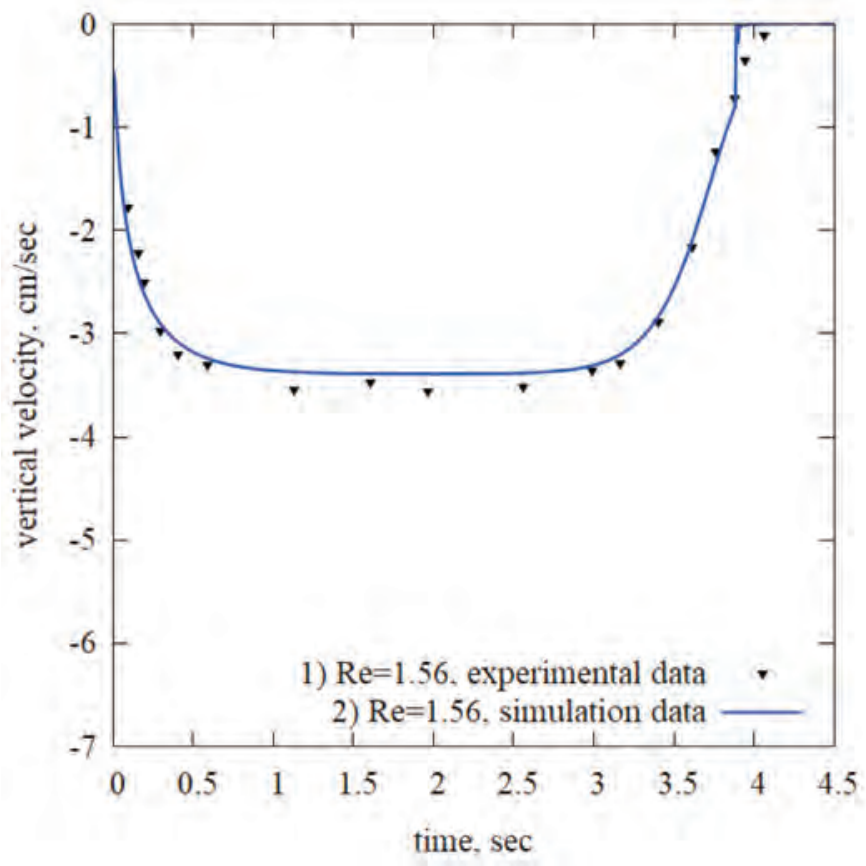

Figure 5 - Vertical velocity of solid particle motion.

Comparison of the simulation data with experimental data at $\mathrm{Re}=1,56$. 


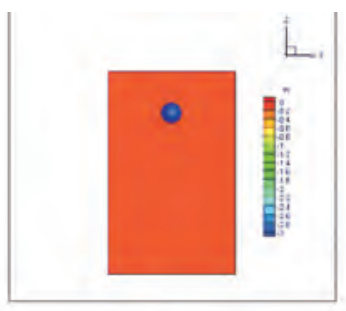

a

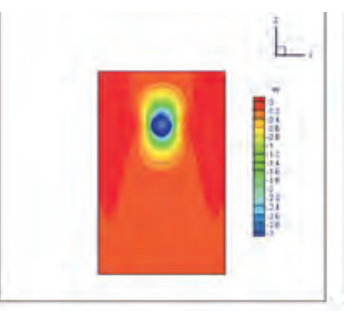

b

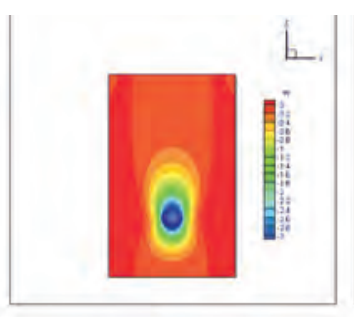

c

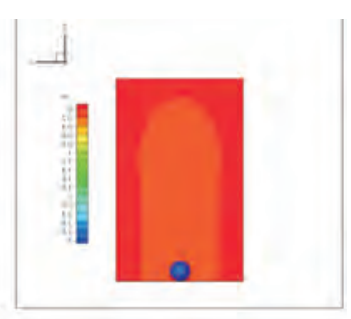

d

Figure 6 - Vertical velocity profiles of solid particle motion on the plane $\mathrm{Y}=0,5$ at times a) $t=0 c$., b) $t=0,3 c$., c) $t=2 c$., d) $t=4 c$.

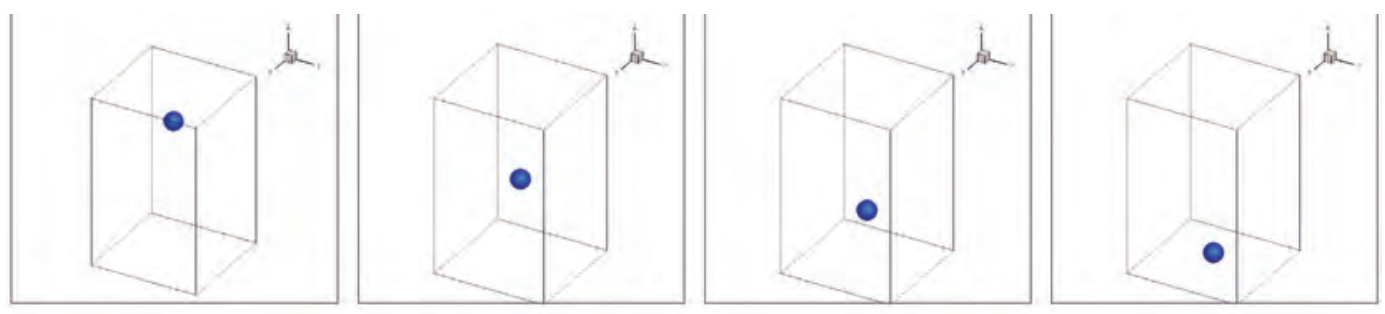

Figure $7-3 \mathrm{D}$ dynamics of solid particle at times a) $t=0 \mathrm{c}$., b) $t=0,3 \mathrm{c}$., c) $t=2 \mathrm{c}$., d) $t=4 \mathrm{c}$.

Conclusion. In this paper, the modeling of solid particle motion in a viscous medium is considered. Numerical simulation is carried out in the computational domain of a parallelepiped shape using the LBM with nineteen lattice velocities. The IBB method is used to effectively determine the boundary condition at the «fluid - solid particle» interface. The derived simulation results are in good agreement with the results of other authors. This means that the developed algorithm may well be applied to solving the problem of the solid particles dynamics in a thermal viscous flow. This result will be obtained and shown in a future research.

This work was supported by grant funding for scientific and technical programs and projects of the Science Committee of the Ministry of Education and Science of the Republic of Kazakhstan, grant no. AP09260528.

\section{REFERENCES}

1 Peskin CS. The immersed boundary method. Acta Numer 2002; 11:479-517.

2 Uhlmann M. An immersed boundary method with direct forcing for the simulation of particulate flows. J Comput Phys 2005;209(2):448-76.

3 Z. Zhang, A. Prosperetti, A second-order method for three-dimensional particle simulation, J. Comput. Phys. 210 (2005) 292-324.

4 T.M. Burton, J.K. Eaton, Fully resolved simulations of particle-turbulence interaction, J. Fluid Mech. 545 (2005) 67-111.

5 K. Yeo, S. Dong, E. Climent, M.R. Maxey, Modulation of homogeneous turbulence seeded with finite size bubbles or particles, Int. J. Multiphase Flow 36 (2010) 221-233. 
6 H. Homann, J. Bec, Finite-size effects in the dynamics of Neutrally buoyant particles in turbulent flow, J. Fluid Mech. 651 (2010) 81-91.

7 Wang L-P, Peng C, Guo Z, Yu Z. Lattice Boltzmann simulation of particle-laden turbulent channel flow. Comput Fluid 2016; 124:226-36.

8 L.-P. Wang, O. Ayala, H. Gao, et al., Study of forced turbulence and its modulation by finitesize solid particles using the lattice Boltzmann approach, Comput. Math. Appl. 67 (2014) 363-380.

9 J. Latt, B. Chopard, O. Malaspinas, M. Deville, A. Michler, Straight velocity boundaries in the lattice Boltzmann method, Phys. Rev. E 77 (2008) 056703.

10 Ch. Peng, Y. Teng, B. Hwang, Zh. Guo, L- P Wang. Implementation issues and benchmarking of lattice Boltzmann method for moving rigid particle simulations in a viscous flow. Computers and Mathematics with Applications 72 (2016) 349-374.

11 M. Bouzidi, M. Fordaouss, P. Lallemand, Momentum transfer of a Boltzmann-lattice fluid with boundaries, 13 (2001) 3452-3459.

12 Zhao W, Yong W-A. Single-node second-order boundary schemes for the lattice Boltzmann method. J Comput Phys 2017;329(6):1-15.

13 Tao S, He Q, Chen B, Yang X, Huang S. One-point second-order curved boundary condition for lattice Boltzmann simulation of suspended particles. Comput Math Applica 2018.

14 T. Krüger, H. Kusumaatmaja, A. Kuzmin, O. Shardt, G. Silva, E.M. Viggen. The Lattice Boltzmann Method. - Switzerland: Springer International Publishing, 2017. - 61-293 p.

15 A. ten Cate, C. H. Nieuwstad, J. J. Derksen, and H. E. A. Van den Akker. Particle imaging velocimetry experiments and lattice-Boltzmann simulations on a single sphere settling under gravity // Physics of Fluids. - 2002. V. 14, N 11. P. $4012-4025$.

\title{
Б. Т. ЖҰМАҒҰЛОВ А. С. ЖҰМӘЛ1,, Б. А. САТЕНОВА ${ }^{2}$
}

\author{
${ }^{1}$ Қазақсстан Республикасы Ұлттық инженерлік академиясы, \\ Алматы құаласы, Қазақсстан \\ ${ }^{2}$ Әл-Фараби атындавы Қазақ Ұлттық Университеті, Алматы құласы, Қазақсттан \\ *e-mail: ainura.z89@gmail.com
}

\section{ТҰТҚЫР ОРТАДАҒЫ ҚАТТЫ БӨЛШЕК ДИНАМИКАСЫН LВМ ПІШІНДЕУ}

Мақұалада тұтқыыр ортадавы жалzыз құатты бөлиектің динамикасын математикалық және компьютерлік модельдеу құарастырылады. Зерттеу нәтижелері Больиманның торль теңудеулері әдісінің (LBM) D3Q19 моделі негізінде жүзеге асырылган 3D сандық алгоритмнің көмегімен алындыл. «Сұйықтық - қ̧атты бөлік» бөлігінің қ̧озгалмаль иекарасы интерполяцияланган кері қуайту (IВB) схемасын қзолдану арқыьль ескеріледі.

$R e=1,56$ үшін құатты бөлшек құозzалысының жылдамдызы мен бөлшек траекториясы алынды. Нәтижелер басқа авторлардың эксперименталды және сандық нәтижелерімен жақссы сәйкес келедi.

Түйін сөздер: LBM, IBB, D3Q19, қ̧атты бөлшек, тұтқыр орта. 
Б. Т. ЖУМАГУЛОВ ${ }^{1}$, Д. Б. ЖАКЕБАЕВ ${ }^{1,2}$, А. С. ЖУМАЛИ ${ }^{1,2}$, Б. А. САТЕНОВА

${ }^{1}$ Национальная инженерная академия Республики Казахстан, Алматы, Казахстан

${ }^{2}$ Казахский национальный университет имени аль-Фараби, Алматы, Казахстан *e-mail: ainura.z89@gmail.com

\section{LВМ- МОДЕЛИРОВАНИЕ ДИНАМИКИ ТВЕРДОЙ ЧАСТИЦЫ В ВЯЗКОЙ СРЕДЕ}

В данной статье рассматривается математическое и компьютерное моделирование динамики одиночной твердой частищь в вязкой среде. Результаты исследования получены с помощью $3 D$ численного алгоритма, осуществленного на базе D3Q19 модели метода решеточных уравнений Больимана (LBM). Движущаяся граница раздела «жидкость - твердая частица» учитывается применением интерполированной схемы обратного отскока (IBB).

Получены скорость движения твердой частищы и траектория частищы при Re $=1,56$. Результаты имеют хоромее согласование с экспериментальными и численными результатами других авторов.

Ключевые слова: LBM, IBB, D3Q19, твердая частица, вязкая среда. 